\title{
THE EARTH ANGLE MOMENT BALANCE, LOW-FREQUENCY ATMOSPHERIC PROCESSES AND RADIOWAVEGUIDES: II. APPLICATION OF AN ADVANCED NON-STATIONARY THEORY FOR DIFFERENT FORMS OF ATMOSPHERE CIRCULATION
}

\author{
A.V. Glushkov, Dr. Sci. (Phys.-Math.), \\ A.A. Svinarenko, Dr. Sci. (Phys.-Math.), \\ S.V. Ambrosov, Cand. Sci. (Geogr.), \\ Yu.Ya. Bunyakova, Cand. Sci. (Geogr.), \\ V.V. Buyadzhi, V.F. Mansarliysky \\ Odessa State Environmental University, 15, \\ LvivskaSt., 65016 Odessa, Ukraine, glushkovav@gmail.com
}

\begin{abstract}
In the paper we present the results of application of a new advanced non-stationary theory of global mechanisms in atmospheric low-frequency processes, the balance of the angular momentum of the Earth, teleconnection effects and atmospheric radio waveguides, for the Pacific ocean region for different forms of the atmosphere circulation. The theory is realized and implemented into Microsystem Technology "GeoMath" and focused on the discovery and testing of new predictors for long-term and very long-forecasts of lowfrequency atmospheric processes. The PC experiments have demonstrated an effectiveness of a new advanced theory in application to modeling balance of angular momentum, the atmospheric moisture turnover in relation to the genesis of tropospheric radio waveguides and succession processes of atmospheric circulation forms (teleconnection, front-genesis) in order to develop new practical sensors in long-term forecasting and modeling of low-frequency atmospheric processes. It is determined a link of tropospheric waveguide with atmospheric moisture circulation and, accordingly, with the shape of the atmospheric circulation over the position of the front sections of (atmospheric fronts as the main drives moisture). Atmospheric moisture cycle is linked with such typical low-frequency process as the angular momentum balance; the latter accounts violation of the atmosphere rotating balance with the Earth.
\end{abstract}

Key words: the balance of the angular momentum of the Earth, low-frequency atmospheric processes, teleconnection, atmospheric waveguides, various forms of atmospheric circulation

\section{INTRODUCTION}

In this paper we present the results of application of a new advanced non-stationary theory of global mechanisms in atmospheric low-frequency processes, the balance of the angular momentum of the Earth, teleconnection effects and atmospheric radio waveguides, for the Pacific ocean region for different forms of the atmosphere circulation. In [1-4] we presented the fundamental basis's of a new advanced non-stationary approach to global mechanisms in atmospheric low-frequency processes, the balance of the Earth angular momentum, teleconnection effects and atmospheric radio waveguides. The approach has been realized as a new geophysical microsystem technology "GeoMath" [2]. The topics studied are of a great interest for modern physics of atmosphere processes [517].

Let us remind according to [4] that one of the key purposes focused on the discovery and testing of new predictors for long-term and very long-forecasts of lowfrequency atmospheric processes. We are talking about the adaptation of the advanced theory of atmospheric macroturbulence applicable to radiofrequency with a view to their possible using along with other as predictors in the long term. The preliminary "Pasific ocean" PC experiments have in whole demonstrated an effectiveness of a developed theory especially in application to modeling balance of angular momentum, the atmospheric moisture turnover in relation to genesis of tropospheric radio waveguides and succession processes of atmospheric circulation forms (teleconnection, front-genesis). But, all preliminary PC experiments were realized on the basis of general stationary theory or simplified (so called short version) non-stationary one. As an sequence, all obtained data could be quantitatively changing, though non essentially.

\section{ADVANCED NON-STATIONARY THEORY FOR BALANCE OF ANGULAR MOMENTUM}

As the key elements of our theory were in details presented earlier [1-4], here we present shortly only the basic advanced aspects. According to [1-4], an advanced nonstationary angular momentum balance equation of in the planetary dynamic movements of air masses is written in the following standard integral form $[2,17]$

$$
\begin{aligned}
& \frac{\partial}{\partial t} \int \rho M d V=\int_{\phi_{1}}^{\phi_{2}} \int_{0}^{H} \int_{0}^{2 \pi} \rho v M d \phi d z d \lambda+ \\
& +\int_{0}^{H} \int_{\phi_{1}}^{\phi_{2}} \int_{0}^{2 \pi}\left(p_{E}^{i}-p_{W}^{i}\right) a \cos \phi d z d \phi d \lambda+ \\
& +\int_{\phi_{1}}^{\phi_{2}} \int_{0}^{2 \pi} \int_{0}^{H} \tau_{0} a \cos \phi d \phi d \lambda 2 \pi,
\end{aligned}
$$

where $M=\Omega a^{2} \cos \varphi+u a \cos \varphi$ - angular momentum; $\Omega$ - the angular velocity of rotation of the Earth; $a$ - radius of the Earth; $\varphi$ - Latitude $\left(\varphi_{1}-\varphi_{2}\right.$ - separated latitudinal belt between the Arctic and polar fronts); $\lambda$ - longitude; 
$u, v$ - zonal and meridional components of the wind speed; $\rho$ - air density; $V$ - the entire volume of the atmosphere in this latitude belt from sea level to the average height of the elevated troposphere waveguide - $H$ (in notations by Oort $H=\infty$ [9]); $p_{E}^{i}-p_{W}^{i}$ - the pressure difference between the eastern and western slopes of the $i$-th mountains; $z$ - height above sea level; $\tau_{0}$ - the shear stress on the surface. From the point of view of physics, the cycle of balance of angular momentum in the contact zones with the hydrosphere and lithosphere becomes a singularity. This singularity can be detected through the occurrence of zones of fronts and soliton-type front. Then the kernel of equation (1) can be defined in the density functional ensemble of complex velocity potential [1]

$$
\begin{gathered}
w=\overline{v_{\infty}} z+\frac{1}{2 \pi} \sum_{k=1}^{n} q_{k} \ln \left(z-a_{k}\right)+ \\
+\frac{1}{2 \pi} \sum_{k=1}^{p} \frac{M_{k} e^{\alpha_{k} i}}{z-c_{k}}-\frac{i}{2 \pi} \sum_{k=1}^{m} \Gamma_{k} \ln \left(z-b_{k}\right)
\end{gathered}
$$

and the complex velocity, respectively, will be

$$
\begin{aligned}
& v=\frac{d w}{d z}=\overline{v_{\infty}}+\frac{1}{2 \pi} \sum_{k=1}^{n} \frac{q_{k}}{z-a_{k}}-\frac{1}{2 \pi} \sum_{k=1}^{p} \frac{M_{k} e^{\alpha_{k} i}}{\left(z-c_{k}\right)^{2}}- \\
& -\frac{i}{2 \pi} \sum_{k=1}^{m} \Gamma_{k} /\left(z-b_{k}\right)
\end{aligned}
$$

where $w$ - complex potential; $v_{\infty}$ - complex velocity general circulation background (mainly zonal circulation); $b_{k}$ - coordinates of vortex sources in the area of singularity; $c_{k}$ - coordinates of the dipoles in the area of singularity; $a_{k}$ - coordinates of the vortex points in areas of singularity; $M_{k}$ - values of momenta of these dipoles; $\alpha_{k}-$ orientation of the axes of the dipoles; $\Gamma_{k}, q_{k}-$ values of circulation in the vortex sources and vortex points, respectively.

In the scheme by Oort [9] the Hadley circulation cell in angular momentum in the north part runs into a zone of the Arctic front, and at the time of the lithosphere it is included in the coverage of the polar front. Convergence of these atmospheric fronts could then close the cycle of atmospheric angular momentum balance in the same frequency range of atmospheric fluctuations without giving effect by an ocean and the lithosphere. Of course, the Hadley tropical cell carries teleconnection of the polar front with southern process by means of the link mechanism which is similar to link between the tropical and polar fronts or the Hadley tropical cell with a cell Hadley of temperate latitudes. The balance of angular momentum in conditions of the close convergence of the Arctic and Polar fronts over the ocean (which is almost always in all seasons and over the continents in the summer and in the transition seasons) is largely respected by centrifugal "pull" moisture along the front section of the polar front to south of the center of the cyclonic-depressive these. Total mass flux in a separate cloud as well as cloud system, is determined by the Arakawa's model. If A is a work of the convective cloud then it consists of the con- vection work and work of down falling streams in the neighbourhood of cloud:

$$
\frac{d A}{d t}=0=\frac{d A}{d t}_{\text {conv }}+\frac{d A}{d t}_{\text {downstr. }} .
$$

It is obvious that

$$
\frac{d A}{d t \text { downstr. }}=\int_{0}^{\lambda} m_{B}\left(\lambda^{\prime}\right) K\left(\lambda, \lambda^{\prime}\right) d \lambda^{\prime} .
$$

Here $m_{B}(\lambda)$ is an air mass, drawn into a cloud with velocity of drawing $\lambda$; if

$$
\begin{gathered}
\frac{d A}{d t} \text { downstr. } \\
\lambda_{\int_{0} K\left(\lambda, \lambda^{\prime}\right) m_{B}\left(\lambda^{\prime}\right) d \lambda^{\prime}+F(\lambda)}=0
\end{gathered}
$$

is an mass balance equation in the convective thermion and $K\left(\lambda, \lambda^{\prime}\right)$ is a nucleus of integral equation (1), which defines dynamical interaction between neighbour clouds then

$$
\beta \int_{0}^{\lambda_{\max }} K\left(\lambda, \lambda^{\prime}\right) m_{B}\left(\lambda^{\prime}\right) d \lambda^{\prime}+F(\lambda)=m_{B}(\lambda) .
$$

This is the Arakawa type equation with accounting for air streams superposition of synoptic process. Its solution is as follows

$$
m_{B}(\lambda)=F(\lambda)+\beta \int_{0}^{\lambda_{\max }} F(s) \Gamma(\lambda, s: \beta) d s,
$$

here $\Gamma(\lambda, s: \beta)$ is an resolventa of the master integral equation, which is given in Refs [1-4].

As usually, we present a resolventa of the integral equation as an expansion in the Loran set cycle in a complex plane $\zeta$; its centre coincides with the centre of the heating spot of a city and internal cycle with its periphery; external one can be moved beyond limits of recreation zone. Then resolventa is as the Loran set (with a as centre of converge for the Loran set):

$$
\begin{gathered}
\Gamma=\sum_{n=-\infty}^{\infty} c_{n}(\zeta-a)^{n}, \\
c_{n}=\frac{1}{2 \pi i} \oint_{|\zeta=1|} \frac{f(\zeta) d \zeta}{(\zeta-a)^{n+1}} .
\end{gathered}
$$

\section{ADVANCED MODEL OF LOW-FREQUENCY AT- MOSPHERIC MOTIONS}

According to [1-4], here we shortly consider an advanced spectral analogue for equation of motion for dynamics of the atmosphere in the low frequency range. As it is well known, the shape of the atmospheric circulation changes its position in space, and the intensity of manifes- 
tations varies in the period up to several days, while inside it implemented processes, lasting a few minutes, such as precipitation. Hydrodynamic equations are set to reasonably high-frequency processes in the atmosphere of the evolution of the cyclonic type of education in the period up to two days, but it is not able to well describe the low-frequency processes such as change of the circulation forms.

The macroturbulent atmosphere equations are lowfrequency ones in its basis and there is a lot of experience of their decision on the basis of spectral methods $[3,4,14,31]$. This allows you to use them for our purposes for the mathematical modeling of the changing forms of circulation and, respectively, for the mathematical parameterization homologues circulation $[13,14]$. Further one should involve coupling moments forecasting model, which is know from the system of the Reynolds equations with average and fluctuation motion.

The technique of using Reynolds tension tensors of the second rank is well known (for example, in the form of an analytical representation). The circuit equations with accounting the Coriolis force in the analytical form can be rewritten as:

$$
\begin{aligned}
& \frac{\partial V^{\prime 2}}{\partial t}=-\frac{i}{a}\left[\overline{V^{\prime 2}} L_{1}(\bar{V})+2 \bar{V} \overline{V^{\prime} L_{1}\left(V^{\prime}\right)}+\overline{V^{\prime 2} L_{1}\left(V^{\prime}\right)}\right]- \\
& -\frac{i}{a}\left[L_{2}(\bar{V}) \overline{V^{\prime} U^{\prime}}+\bar{V} \overline{U^{\prime} L_{2}\left(V^{\prime}\right)}+\bar{U} \overline{V^{\prime} L_{2}\left(V^{\prime}\right)}+\overline{V^{\prime} U^{\prime} L_{2}\left(V^{\prime}\right)}\right]+ \\
& +4 \omega i \cos \theta \overline{V^{\prime 2}}+\frac{2 i}{a} \overline{V^{\prime} L_{6}\left(\Phi^{\prime}\right)}, \\
& \frac{\partial U^{\prime 2}}{\partial t}= \\
& =-\frac{i}{a}\left[\overline{V^{\prime} U^{\prime} L_{3}}(\bar{U})+\bar{V} \overline{U^{\prime} L_{3}\left(U^{\prime}\right)}+\bar{U} \overline{V^{\prime} L_{3}\left(U^{\prime}\right)}+V^{\prime} U^{\prime} L_{3}\left(U^{\prime}\right)\right]- \\
& -\frac{i}{a}\left[\overline{U^{\prime 2}} L_{4}(\bar{U})+2 \bar{U} \overline{U^{\prime} L_{4}\left(U^{\prime}\right)}+\overline{U^{\prime 2} L_{4}\left(U^{\prime}\right)}\right]- \\
& -4 \omega i \cos \theta \overline{U^{\prime 2}}+\frac{2 i}{a} \overline{U^{\prime} L_{5}\left(\Phi^{\prime}\right)}, \\
& \frac{\partial \overline{V^{\prime} U^{\prime}}}{\partial t}=-\frac{i}{2 a}\left[\overline{V^{\prime 2}} L_{3}(\bar{U})+2 \bar{V} \overline{V^{\prime} L_{3}\left(U^{\prime}\right)}+\overline{V^{\prime 2} L_{3}\left(U^{\prime}\right)}\right]- \\
& -\frac{i}{2 a}\left[\overline{V^{\prime} U^{\prime} L_{4}}(\bar{U})+\bar{U} \overline{V^{\prime} L_{4}\left(U^{\prime}\right)}++\bar{V} \overline{U^{\prime} L_{4}\left(U^{\prime}\right)}+\overline{V^{\prime} U^{\prime} L_{4}\left(U^{\prime}\right)}\right]+ \\
& +\frac{i}{a} \overline{V^{\prime} L_{6}\left(\Phi^{\prime}\right)}-\frac{i}{2 a}\left[\overline{U^{\prime 2}} L_{2}(\bar{V})+2 \bar{U} \overline{U^{\prime} L_{2}\left(U^{\prime}\right)}\right]- \\
& -\frac{i}{2 a}\left[\overline{U^{\prime} V^{\prime}} L_{1}(\bar{V})+\bar{U} \overline{V^{\prime} L_{1}\left(V^{\prime}\right)}++\bar{V} \overline{U^{\prime} L_{1}\left(V^{\prime}\right)}+\overline{V^{\prime} U^{\prime} L_{1}\left(V^{\prime}\right)}\right],
\end{aligned}
$$

where

$$
\begin{gathered}
L_{j}=\frac{\partial(\ldots)}{\partial \theta}-(-1)^{j} \frac{i}{\sin \theta} \frac{\partial(\ldots)}{\partial \lambda}+b_{j} \operatorname{ctg} \theta(\ldots), \\
b_{j}=1, j=1,4 ; b_{j}=-1, \mathrm{j}=2,3 ; b_{j}=0, j=5,6 .
\end{gathered}
$$

In many earlier papers (see for example, [10]) authors used the simplified approximation, which results to remaining only two operators, say, the equation (9c)

$$
\frac{\partial \overline{V^{\prime} U^{\prime}}}{\partial t}=\frac{i}{a} \overline{V^{\prime} L_{6}\left(\Phi^{\prime}\right)},
$$

expressing $\Phi^{\prime}$ through $\varphi$ complex potential of the velocity $w$, and the velocity components $V^{\prime}$ - in terms of functions $\psi$ of the same velocity potential. Naturally, the equations for tensor of the turbulent tensions

$$
\begin{aligned}
& \frac{\partial \overline{u_{i}^{\prime} u_{j}^{\prime}}}{\partial t}+\frac{\partial}{\partial x_{k}}\left(\overline{u_{k}} \cdot \overline{u_{i}^{\prime} u_{j}^{\prime}}+\overline{u_{k}^{\prime} u_{i}^{\prime} u_{j}^{\prime}}\right)+\frac{\partial \overline{p^{\prime} u_{i}^{\prime}}}{\partial x_{j}}+\frac{\partial \overline{p^{\prime} u_{j}^{\prime}}}{\partial x_{i}}= \\
& =-\overline{u_{i}^{\prime} u_{k}^{\prime}} \frac{\partial \overline{u_{j}}}{\partial x}-\overline{u_{j}^{\prime} u_{k}^{\prime}} \frac{\partial \overline{u_{i}}}{\partial x}+\overline{p^{\prime}\left(\frac{\partial u_{i}^{\prime}}{\partial x}+\frac{\partial u_{j}^{\prime}}{\partial x}\right)} .
\end{aligned}
$$

The kinetical energy of fluctuations is $b^{2}=\overline{u_{k}^{\prime} u_{k}^{\prime}}$.

The corresponding eq.

$$
\begin{aligned}
& \frac{\partial b}{\partial t}+\frac{\partial u_{k} b^{2}}{\partial x_{k}}+\frac{\partial}{\partial x_{k}}\left(\overline{u_{k}^{\prime} u_{i}^{\prime} u_{j}^{\prime}}+2 \overline{u_{k}^{\prime} p^{\prime}}\right)= \\
& =-2 \overline{u_{k}^{\prime} u_{i}^{\prime}} \frac{\partial u_{i}}{\partial x_{k}}-2 \frac{g}{\theta_{0}} \overline{w^{\prime} \theta^{\prime}}
\end{aligned}
$$

Here $\theta$ is potential temperature. Velocity's correlates are as follows:

$$
\begin{gathered}
\overline{u_{i}^{\prime} u_{j}^{\prime} u_{k}^{\prime}}=-b \lambda_{1}\left(\frac{\partial \overline{u_{i} u_{j}}}{\partial x_{k}}+\frac{\partial \overline{u_{i} u_{k}}}{\partial x_{j}}+\frac{\partial \overline{u_{j} u_{k}}}{\partial x_{i}}\right), \\
\overline{u_{k}^{\prime} u_{j}^{\prime} \theta^{\prime}}=-b \lambda_{2}\left(\frac{\partial \overline{u_{k}^{\prime} \theta^{\prime}}}{\partial x_{j}}+\frac{\partial \overline{u_{j} \theta^{\prime}}}{\partial x_{k}}\right), \\
\overline{u_{i} \theta^{\prime 2}}=-b \lambda_{3}\left(\frac{\partial \overline{\theta^{\prime 2}}}{\partial x_{i}}\right) ; \overline{p^{\prime} \frac{\partial \theta^{\prime}}{\partial x_{i}}}= \\
=-\frac{b}{3 l_{1}} \overline{u_{i} \theta^{\prime}}-\frac{1}{3} \sigma_{i 3} \frac{g}{\theta_{0}} \overline{\theta^{\prime 2}}, \\
\quad \frac{\partial u_{i}}{p^{\prime}\left(\frac{\partial u_{j}}{\partial x_{j}}\right)}=-\frac{b}{3 l_{1}}\left(\overline{u_{i} u_{j}}-\frac{1}{3} \sigma_{i j} b^{2}\right)+ \\
+c b^{2}\left(\frac{\partial \overline{u_{i}}}{\partial x_{j}}+\frac{\partial \overline{u_{j}}}{\partial x_{i}}\right) .
\end{gathered}
$$

Here $c, l_{1}, \lambda_{\mathrm{i}}$ are constants which define the scales of turbulent vortexes and measure of their influence on the averaged motion and atmosphere turbulence anisotropy. Components of tensor of the turbulent tensions are $\left(v_{1, n}\right.$ spectral modes of velocity field) are given in [1-4].

\section{RESULTS AND CONCLUSIONS}

In ref.[4] we presented the results of calculation of changes in the height of elevated tropospheric wave guide in the $M_{1}$ form of circulation (look Fig. 1 [4]). Here we present the same results for the $\mathrm{M}_{2}$ form, namely, average height of tropospheric waveguide according to the season within the 1500-2500 m; changes desired heights are in the range of $50-500 \mathrm{~m}$. It is important for long-term forecasting only a sign of abnormality of heights of the ra- 
diowaveguide and not their numerical characteristics. Fig. 2 corresponds to wind flows presented an anomaly of the stream function, where the direction of the velocity vector corresponds to the positive values that were left of the stream; the changes in the function of the current make - maximum value: $\sim 20 \cdot 10^{6} \mathrm{~m}^{2} \mathrm{~s}^{-1}, \sim 1.2 \cdot 10^{6} \mathrm{~m}^{2} \mathrm{~s}^{-1}$ ).

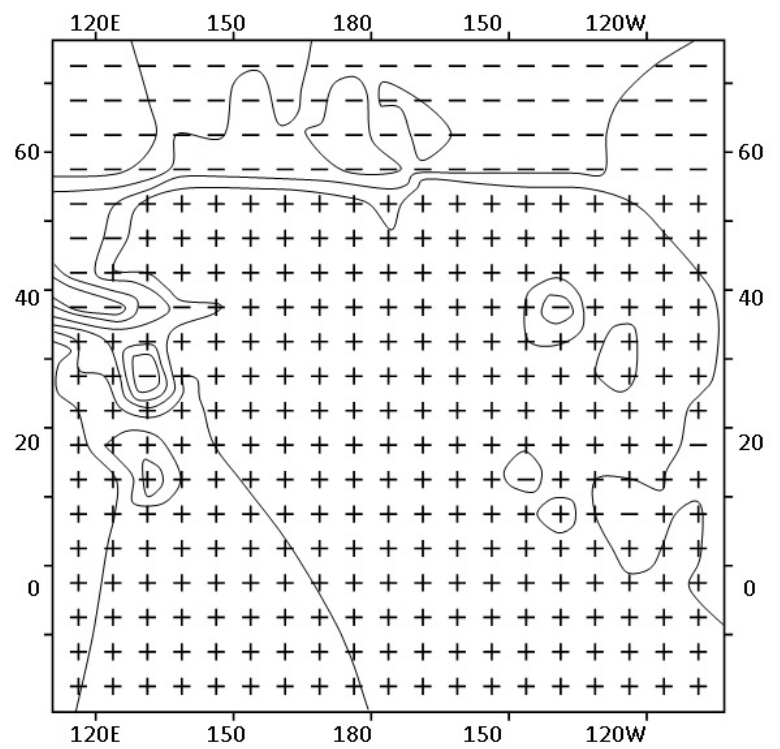

Fig. 1 - Changing the height of the elevated tropospheric radiowaveguide (see the text).

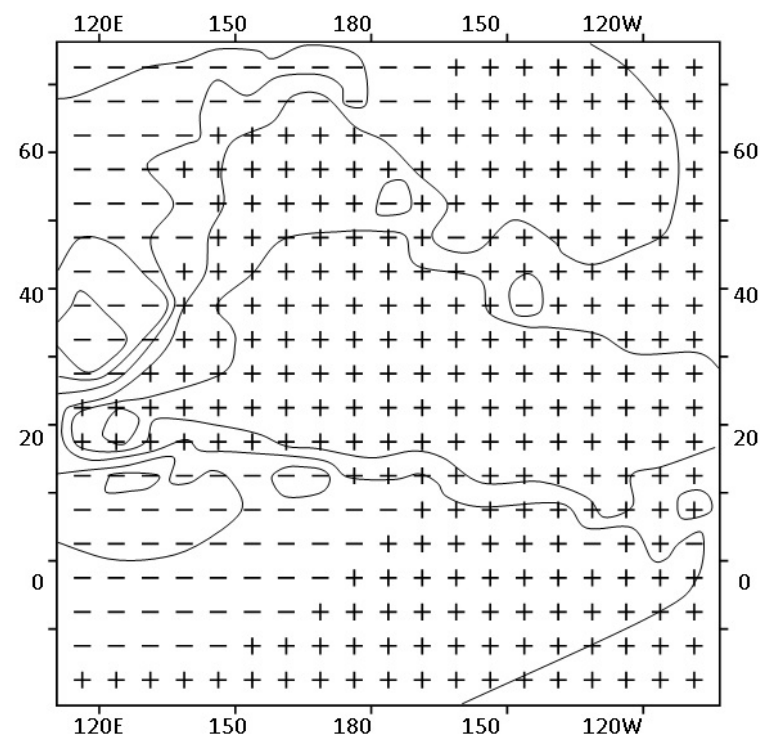

Fig. 2 - The flow function for the situation depicted in Fig. 1.

For the form $\mathrm{M}_{2}$ (Fig. 1) there is a sharp worsening of the process near the Japan, which it is revealed a sharp rise of height of the elevated tropospheric waveguide, as well as general background of raising its height above the Pacific Ocean over the summer in a case of the form $\mathrm{M}_{2}$. According to the current function (Fig. 2) it is clearly revealed the transfer of angular momentum to the south along the Asian continent on the system of fronts, manifested in the cyclonic depressions, which are characteris- tic for the Asian continent in a case of the form $\mathrm{M}_{2}$.

Summering the above presentation, let us remind [1-4] that the atmospheric moisture cycle is associated with the typical low-frequency performance of the process as the balance of angular momentum. Last imbalance characterizes the rotation of the atmosphere together with the Earth, which may lead to the development of meridional processes with the implementation of the mass transfer of air and steam between tropical latitudes (with a linear velocity) and slowly rotating air masses of polar latitudes (in fact it is a slow process teleconnection). Dynamics and characteristics of atmospheric radio waveguide is just related to the teleconnection and, thus, the forms of circulation, with the processes of succession of these forms. Imbalance of angular momentum can not remain without consequences in the atmosphere due to the rather large forces involved in the desired dynamics. Naturally imbalance causes the effects of the singularity, i.e. sharp reaction of the atmosphere in an attempt to eliminate it.

\section{REFERENCES}

1. Glushkov A.V. Renorm-group and fractal approach to turbulence spectrum in planetary atmosphere system, "cosmic plasma - galactic cosmic rays". Ukr. gidrometeorol. ž. - Ukranian hydrometeorological journal, 2013, no. 12, pp.25-30.

2. Glushkov A.V., Ambrosov S.V., Bunyakova Yu.Ya., Mansarliysky V.F. Modelling balance of the earth angle moment, atmospheric processes and radiowaveguides: Advanced non-stationary theory. Ukr. gidrometeorol. ž. - Ukranian hydrometeorological journal, 2014, no.15, pp.59-64.

3. Ambrosov S.V., Serga E.N., Mansarliysky V.F., Kol'tsova N.Yu. The balance of the angular momentum of the Earth and atmospheric Radio waveguides: Elements of non-stationary theory. Visn. Odes. derž. ekol. unìv. - Bulletin of Odessa state environmental university, 2012, vol.14, pp.234-239.

4. Glushkov A.V., Svianrenko A.A., Ambrosov S.V., Bunyakova Yu.Ya., Buyadzhu V.V., Mansarliysky V.F. The Earth Angle Moment Balance, Low-Frequency Atmospheric Processes And Radiowaveguides: Application of an Advanced NonStationary Theory. Visn. Odes. derž. ekol. unìv. - Bulletin of Odessa state environmental university , 2015, vol.19, pp.131136.

5. Glushkov A.V., Khokhlov V.N., Tsenenko I.A. Atmospheric teleconnection patterns and eddy kinetic energy content: wavelet analysis. Nonlinear Processes in Geophysics, 2004, vol.11, pp.285-293.

6. Loboda N.S., Glushkov A.V., Khokhlov V.N., Lovett L. Using non-decimated wavelet decomposition to analyze time variations of North Atlantic Oscillation, eddy kinetic energy, and Ukrainian precipitation. Journal of Hydrology. The Netherlands: Elsevier, 2006, vol.322, no.1-4, pp.14-24.

7. Glushkov A.V., Svinarenko A.A., Buyadzhi V.V., Zaichko P.A., Ternovsky V.B. Adv.in Neural Networks, Fuzzy Systems and Artificial Intelligence, Series: Recent Adv. in Computer Engineering. Gdansk: WSEAS, 2014, vol.21, pp.143-150.(Ed.: J. Balicki)

8. Mansarliysky V. Multifractal modeling characteristics of temporal indexes of North-Atlantic, Southen oscillations, and vortex kinetical energy in middle and tropic latitudes. Ukr. gidrometeorol $\check{z}-U k r$.hydrometeorological journal, 2012,no.10,pp.171-175. 
9. Peixoto J.P., Oort A.H. Physics of Climate. N.-Y.: AIP, 1992. $520 \mathrm{p}$;

10. Von Storch J. Angular momenta of Antarctic, Arctic Oscillations. J.Clim., 2000, vol.13, pp.681-685.

11. Barnston A.G., Livezey R.E. Classification, seasonality and persistence of low-frequency atmospheric circulation patterns Month.Weather Rev., 1987, vol.115, pp.1083-1126.

12. Wallace J.M., Gutzler D.S. Teleconnections in the geopotential height field during the Northern Hemisphere winter. Month.Weather Rev., 1987, vol.109, pp.784-812.

13. Arakava A., Schubert W.H. Interaction of cumulus cloud ensemble with the large-scale environment. Part I. J. Atmos. Sci., 1974, vol. 31, pp. 674-701.

14. Wang C. ENSO, climate variability, and the Walker and Hadley circulations. In: The Hadley Circulation: Present, Past, and Future. Berlin: Springer, 2004, pp.131-164. (Eds: Diaz H.F., Bradley R.S.)

15. Girs A.A. Long-term fluctuations in atmospheric circulation and long-term meteorological forecasts. Leningrad: Hydrometeoizdat, $1991,280 \mathrm{p}$

16. Khokhlov V., Glushkov A., Loboda N. On the nonlinear interac- tion between global teleconnection patterns. Quart. Journ. of Royal Meteo.Soc., 2006, vol.132, pp. 447-465.

17. Glushkov A.V., Rusov V.N., Loboda N.S., Khetselius O.Yu., Khokhlov V.N., Svinarenko A.A., Prepelitsa G.P. On possible genesis of fractal dimensions in the turbulent pulsations of cosmic plasma - galactic-origin rays - turbulent pulsation in planetary atmosphere system. Adv. Space Research. Elsvier, 2008, vol.42, no.9, pp.1614-1617.

18. Rusov V.D., Glushkov A.V., Vaschenko V.N., Myhalus O.T., Bondartchuk Yu.A. et al. Galactic cosmic rays - clouds effect and bifurcation model of the earth global climate. Part 1. Theory. Journal of Atmospheric and Solar-Terrestrial Physics. Elsevier, 2010, vol.72, pp.498-508.

\title{
БАЛАНС УГЛОВОГО МОМЕНТА ЗЕМЛИ, НИЗКОЧАСТОТНЫЕ АТМОСФЕРНЫЕ ПРОЦЕССЫ И РАДИОВОЛНОВОДЫ: ПРИМЕНЕНИЕ УСОВЕРШЕНСТВОВАННОЙ НЕСТАЦИОНАРНОЙ ТЕОРИИ
}

А.В. Глушков, д-р ф.-м. н., проф.,

А.А. Свинаренко, д-р ф.-м. н., проф.,

С.В. Амбросов, к.геогр. н., доц.,

Ю.Я. Бунякова к.геогр. н., доц.,

В.В.Буяджи, В.Ф. Мансарлийский

\author{
Одесский государственный экологический университет, \\ ул. Львовская,15 ,65016, Одесса, Украина, glushkovav@gmail.com
}

\begin{abstract}
В работе, продолжающей наши предыдущие исследования, представлены результаты применения новой усовершенствованной нестационарной теории глобальных механизмов в низкочастотных атмосферных процессах, баланса углового момента Земли, эффектов телеконнекции и атмосферных радиоволноводов для региона Тихого океана для различных форм циркуляции. Теория реализована и имплементирована в микросистемную технологию "GeoMath" и ориентирована на открытие и тестирование новых предикторов для долгосрочного и сверхдолго-срочного прогнозирования низкочастотных атмосферных процессов. ПК эксперименты продемонстрировали эффективность новой нестационарной теории в моделировании баланса углового момента, атмосферного влагооборота в дальнейшей связи с генезисом тропосферных радиоволноводов и преемственностью форм атмосферной циркуляции (телеконнекция, генезис фронтов) и разработкой новых практических сенсоров долгосрочного прогнозирования и моделирования низкочастотных атмосферных процессов. Установлена связь тропосферного радиоволновода с атмосферным влагооборотом и соответственно с формой атмосферной циркуляции через положение фронтальных разделов (атмосферных фронтов как основных накопителей влаги). Атмосферный влагооборот связан с таким типично низкочастотным процессом как выполнение баланса углового момента; последний характеризует нарушение баланса вращения атмосферы вместе с Землей.
\end{abstract}

Ключевые слова: баланс углового момента Земли, низкочастотные атмосферные процессы, телеконекция, атмосферные радиоволноводы, различные формы атмосферной циркуляции 


\section{БАЛАНС КУТОВОГО МОМЕНТУ ЗЕМЛІ, НИЗЬКОЧАСТОТНІ АТМОСФЕРНІ ПРОЦЕСИ ТА РАДІОХВИЛЬОВОДИ: ЗАСТОСУВАННЯ УДОСКОНАЛЕНОЇ НЕСТАЦІОНАРНОЇ ТЕОРІЇ}

О.В. Глушков, д-р ф.-м. н., проф.,

А.А. Свинаренко, д-р ф.-м. н., проф.,

С.В. Амбросов, к.геогр. н., доц.,

Ю.Я. Бунякова к.геогр. н., доц.,

В.В.Буяджи, В.Ф.Мансарлійський

Одеський державний екологічний університет, вул. Львівська, 15, 65016 Одеса, Украӥна, glushkovav@gmail.com

У роботі, що продовжує наші попередні дослідження, представлені результати застосування нової вдосконаленої нестаціонарної теорії глобальних механізмів в низькочастотних атмосферних процесах, балансу кутового моменту Землі, ефектів телеконнекціі і атмосферних радіохвилеводів для регіону Тихого океану для різних форм циркуляції. Теорія реалізована та імплементована в мікросистемну технологію "GeoMath" і орієнтована на відкриття і тестування нових предикторів для довгострокового i наддовга-термінового прогнозування низькочастотних атмосферних процесів. ПК експерименти продемонстрували ефективність нового нестаціонарної теорії в моделюванні балансу кутового моменту, атмосферного влагооборота у зв'язку з генезисом тропосферних радіохвилеводів і наступністю форм атмосферної циркуляції (телеконнекція, генезис фронтів) і подальшою розробкою нових практичних сенсорів довгострокового прогнозування і моделювання низькочастотних атмосферних процесів. Встановлено зв'язок тропосферного радіохвилеводу з атмосферним вологозворотом і відповідно 3 формою атмосферної циркуляції через положення фронтальних розділів (атмосферних фронтів як основних накопичувачів вологи). Атмосферний вологозворот пов'язаний з таким типово низькочастотним процесом як виконання балансу кутового моменту; останній враховує порушення балансу обертання атмосфери разом із Землею.

Ключові слова: баланс кутового моменту Землі, низькочастотні атмосферні процеси, телеконекція, атмосферні радіохвильоводи, різні форми атмосферної циркуляції 